\title{
POWER, DISCOURSE AND IDEOLOGY: CHALLENGING ESSEN- TIALIST NOTIONS OF RACE AND IDENTITY IN INSTITUTIONS OF HIGHER LEARNING IN SOUTH AFRICA
}

\section{Sewpaul}

\section{INTRODUCTION}

Professor Malegapuru Makgoba and Professor Sipho Seepe, while serving as the acting ViceChancellors of the then University of Natal (now the University of KwaZulu-Natal) and of Vista University, respectively, were authorised by the Minister of Education at the time, Kader Asmal, to produce a document that charted the way forward for transformation in higher education. This responsibility, assigned to Kader Asmal by the State President, Thabo Mbeki, was delegated to Makgoba and Seepe within the framework of regular interactions with the State President (Seepe, 2004). Thus it would appear that the attempt toward drawing up the agenda for educational transformation took place within a broader political project. The resultant paper appeared as a key chapter "Knowledge and Identity: An African Vision of Higher Education Transformation" (Makgoba \& Seepe, 2004) in the book Towards an African Identity in Institutions of Higher Learning edited by Seepe (2004). My paper, which had its genesis in an invitation to present a paper at the launch of the book, is based on a critique of Makgoba's and Seepe's essentialist notion of an African identity and their call to replace the Eurocentric with the Afrocentric.

My anxieties about challenging the views of two powerful, politically connected, high-profile academics (one being the Vice-chancellor at the institution, University of KwaZulu-Natal (UKZN), where I am employed) at the launch were assuaged by their reassurances. In calling for debate and critique Makgoba and Seepe made the point that "everything before us is nothing but an unfinished story that can still be changed, shaped and authored" (2004:15), even as they endorsed the ideology of an African identity for institutions of higher learning, and hoped that theirs is an ideology that will become "universally accepted" (2004:14). More important, however, were the dictates of my conscience. As educators - more specifically, social work educators who are committed to social inclusion, human rights and social justice - it is imperative that we critically interrogate views regarding identity and race that hold possibilities for fostering exclusion, ethnocentricism and hate, which may in turn pave the way for violence and genocide. I am aware of the possibility that, in presenting my views, I might be accused of being Afropessimistic - that the paper might be reduced to an expression of my dislike of Afrocentricism. However, my central concern is about Makgoba's and Seepe's (2004) call to replace one hegemonic discourse, that of Eurocentricism, with another hegemonic discourse, Afrocentricism, and the possible negative consequences of this for South Africa broadly, and for South African institutions of higher learning more specifically - the debates are not restricted to UKZN.

Given the impact of over 300 years of colonialism and almost 50 years of apartheid, there can be no denial that a Western hegemony has become inscribed into South African society and our academic institutions. There is, unarguably, a need for an emancipatory pedagogy to develop an ethos of scholarship that overcomes colonial mental slavery, and one that addresses local and national context-specific realities while being cognisant of, and responsive to, international issues and the multifaceted consequences of globalisation. Drawing on the work of writers such as Freire $(1970 ; 1973)$ and Giroux $(1983 ; 1994 ; 1997)$ I argue that such a scholarship must work towards a politics of resistance, where necessary, a politics of hope, and towards an insurgent multiculturalism with a consistent striving for a deepening of democracy. (See Sewpaul (2003a) 
for strategies by which this might be achieved, as it is not within the scope of this paper to provide full details). Whether or not such a scholarship ought to be exclusively framed as an "Afrocentric" scholarship, shaped by and inscribed with what is termed "an African Identity" are the central issues that I deal with in this paper.

Adopting the postmodernist form of social criticism and the methodology of critical discourse analysis, I interrogate the apparently totalising discourses proposed by Makgoba and Seepe (2004) and, in contrast, I place the emphasis on the contingent, the specific and the relational. The substitution of one hegemonic discourse, that of Eurocentricism, with that of another hegemonic discourse, Afrocentricism, I argue, is to continue modernism's binary classifications, and patterns of inclusion and exclusion that are antithetical to the democratic ideals of South African society. It would appear that Makgoba and Seepe (2004) aimed to adopt the stance of the post-colonial critic who frames writing into a form of a textual insurgency. Drawing on the work of Pratt, Castle (2001:xiii) posits that a textual insurgency is where the "...native intellectual crafts or forges a new discourse, a new literary style, a way of singing or dancing that expresses a native point of view in contest with colonialist discourse. It is an agnostic mode of national self-fashioning that does not, in the end, succumb to the seduction of neocolonialist solutions to native problems" (italics in the original).

However, the contradictory positions adopted by Makgoba and Seepe (2004) are reflected in their attempt at a post-colonialist writing, while reinforcing colonialist and apartheid patterns of inclusion and exclusion. As ideological critique forms the basis of my paper, I begin by elucidating the relationship between power, discourse and ideology as informed by a postmodern theoretical formulation. Wetherell and Potter (1992:33) argue that "to describe someone's opinions as ideological is to mount a critique of those opinions." Given that authors are the products of their social, political, cultural, economic and historical processes, they are both consciously and unconsciously influenced by and in turn influence, and become constitutive of, dominant paradigms and ideologies. Ideological critique involves a commitment to critique of some positions, an engagement with ways in which power is exercised and in forms of argumentative practice. My critique revolves around interrogating the relationship between power, discourse and ideology, exploring the relevance of race, the possible implications of Afrocentricism and an African identity in relation to dynamics of inclusion and exclusion, and questioning the legitimacy of the notion of a single essentialist identity.

\section{POWER, DISCOURSE AND IDEOLOGY}

Postmodernism, underscored by critical pedagogy, is concerned with examining how institutions, knowledge, language, ideology and social relations are inscribed in power in different ways. Peller (cited in Giroux 1992:53) contends that:

"Postmodernism suggests that what has been presented in our social-political and our intellectual traditions as knowledge, truth, objectivity, and reason are actually merely the effects of a particular form of social power, the victory of a particular way of representing the world that then presents itself as beyond mere interpretation, as truth itself."

One of the dangers of race discourse is that "what is assumed to be 'true' becomes in some sense non-social, beyond investigation" (Wetherell \& Potter, 1992:67) - a sacred terrain not to be entered. These authors go on to propose that rather than question the truth of certain "facts", we should "ask how these facts are constructed as facts" and what might be the possible consequences of particular truths or facts that we lay claim to (1992:67). This approach has particular salience in 
my analysis of the article by Makgoba and Seepe (2004). Foucault (1980:131) argues the following in relation to truth and power:

“Truth isn't outside power, or lacking in power: contrary to a myth whose history and functions would repay further study, truth isn't the reward of free spirits, the child of protracted solitude, nor the privilege of those who have succeeded in liberating themselves. Truth is a thing of this world: it is produced by multiple forms of constraint. And it induces regular effects of power (emphasis mine)."

Based on the above, it becomes understandable then that from a post-modernist perspective legitimisation in the direction of universal consensus (Habermas, 1996) is viewed as an "outmoded and suspect value" (Lyotard, 2003:272). Lyotard (2003:264) contended that “...the grand narrative has lost its credibility, regardless of what mode of unification it uses, regardless of whether it is a speculative narrative or a narrative of emancipation." For Lyotard (2003) grand narratives do not problematise their own legitimacy; instead they deny the historical and social construction of their own first principles and in doing so negate the importance of difference, contingency and particularity. This argument, which I return to later, is relevant to Makgoba's and Seepe's given regarding the value of an African identity and an Afrocentric perspective in higher education, with the exhortation that it becomes "universally accepted so that implementation can soon begin" (Makgoba \& Seepe, 2004:14, emphasis mine).

Postmodernists argue that there is a link between knowledge, power and domination. Williams and Sewpaul (2004) assert that there is a need for critical interrogation of all forms of discursive formations in the interest of democracy and of social change. Terre Blanche and Durrheim (1999:149-151) contend that discourse analysis is based on the assumption that "the human lifeworld is fundamentally constituted in language, and that language itself should therefore be the object of study." They qualify this by stating that such study should not be "in the first place about language per se, but about interpreting the social world as a kind of language, i.e. as a system of meanings and practices that construct reality." In comparison, Fairclough's (1989) approach is more nuanced. He points out that language is a social practice and as such is shaped by, as well as shapes, other forms of social practice. In other words, he does not claim a dominance of language over other social phenomena, but emphasises their mutual interaction and influence.

As we speak, think, act communicate and interact, we do so within the constraints of the language, terminology and conceptual boundaries that exist around us. How we interpret our social realities is restricted by the kind of language available to us, or the language we choose to use - whether oral and/or written language. And by means of terminology, a whole range of assumptions slip into our minds that do not normally come to judgement - unless we consciously analyse the particular meanings they carry. These are common sense assumptions, which are necessary prerequisites for us to engage in our daily interactions with one another, to meet our role expectations in our various subject positions, and to make sense of the discourses we engage with. Common sense assumptions facilitate interaction precisely because they are referred to, recalled and reproduced implicitly, rapidly and without time-consuming processes of reflecting upon them, their validity, their morality or their congruence with one's value systems. People are thus more often than not unaware that they are making these assumptions, a view supported by Gramsci (1971), who differentiated between common sense and good sense, with the latter meaning common sense that has been subject to critical interrogation.

Sewpaul and Holscher (2004) argue that, if language imposes a particular interpretation that constitutes only one out of several ways of looking at social reality, its use actively shapes, rather than merely describes, social reality. Discourses, then, must of necessity be subject to power and 
contestation, for language can be used to further the interests of some societal groups at the possible expense of others. "In every society, the production of discourse is at once controlled, selected, organised and redistributed by a certain number of procedures" (Foucault cited in Tomlinson, 1991:8), so as to exercise and to ward off challenges to that exercise of power.

For Wetherell and Potter (1992:60) ideology as well as discourse "...becomes implicated in the very instantiation and maintenance of social and economic relations." Here ideology is seen primarily as a form of practical action reflected in policy statements, in the statements of spin doctors, memos, the media, daily conversations, anecdotes, stories and so on. Thus ideology is an "active, compelling and a pervasive part of the fabric of social life" (Wetherell \& Potter, 1992:61), serving not merely to reflect society and social formations but as constitutive of society. According to Stuart Hall (cited in Wetherell \& Potter, 1992:63):

"... how things are represented and the "machineries" and regimes of representation in a culture do play a constitutive, and not merely a reflexive, after-the-event, role. This gives questions of culture and ideology, and the scenarios of representation subjectivity, identity, politics - a formative, not merely an expressive, place in the constitution of social and political life."

\section{THE RELEVANCE OF RACE}

Race is a concept rooted in colonial conquest and power, designed to oppress and enslave some groups of people, and to create a politics of domination and of subjection that has persisted over centuries and on a universal basis. It is a concept that is socially constructed and reproduced through the processes of racism and race thinking and race categorisation (Alcoff, 2002; Ballard, 2002; Maré, 2002). Race is essentially irrelevant. Race is also unreal, and all too often bound with the notion of nation and distant ancestral lineage. However, race has taken on what Maré (2001:75, quoting Nobles), terms "an illusion of ordinariness", where on the basis of phenotype or one's biological manifestations in terms of skin colour, texture of hair and so on people have attached to them certain social descriptors and cultural extensions that have come to be widely accepted.

While race is irrelevant and unreal it is, paradoxically, one of the most important social categories in our lives. Race has become inscribed into our collective consciousness and our individual psyches, and its influence permeates all of our lived experiences. This is efficiently summed up in the words of Linda Alcoff (2002:13): "Race is irrelevant, but all is race". She argues that the fact that race has lost its scientific credibility does not mean that it has lost its ontological status, and goes on to maintain that:

"In the very midst of our contemporary scepticism toward race stands the compelling social reality that race, or racialised identities, have as much political, sociological and economic salience as they ever had. Race tends toward opening up or shutting down job prospects, career possibilities, available places to live in, potential friends and lovers, reactions from police, credence from jurors, and presumptions by one's students [and one's colleagues!]. Race may not correlate with clinical variations, but it persistently correlates with statistically overwhelming significance in wage levels, unemployment levels, poverty levels and the likelihood of incarceration.” (Alcoff, 2002:15)

Makgoba and Seepe (2004) appropriately problematise the consequences of colonialism and the challenges for contemporary higher education in the following way: "We have to face and indeed overcome the penalties of a colonial history: the valorization of western academia, insufficient levels of pride and faith in African achievements, a heritage of complex racial dynamics, and unequal distribution of national resources." The quintessential response to this problemetisation 
for them lay in the formation of an African identity in higher education, “....an identity that will ... give us a new consciousness - a being in the world and a belonging to the world" (Makgoba \& Seepe, 2004:19, emphasis mine).

Makgoba and Seepe claim that the African identity and the Afrocentricity that they speak of "...is not a matter of colour" (2004:42). Their assertion is that the African identity "becomes a mark of belonging to a common political community, a commitment to forging a common future" (2004:28). There are contradictions in the use of the concept "African" which do have implications for patterns of inclusion and exclusion, a debate I shall return to later in this paper.

To stay with the present issue, I support Lansink's (2004:123) caution about “...loading of the category African with so much meaning that it forecloses the possibility of its uses." It also has the potential to foreclose debates around the real issues surrounding race, and other categories used as the basis of social differentiation, social stratification and exclusion in South Africa, as Phumla Gqola (2001) so poignantly elucidates. It is, as she claims, naïve to assume that discourses of racism, sexism and class would disappear overnight. The overwhelming assumption of a unitary African identity holds the potential to suppress all other discourses around race and identity. This is more so when people in certain privileged spaces become the source of "authorised truths in the post-apartheid dispensation" (Gqola, 2001:96).

Gqola makes a sharp attack on "rainbowism", arguing that it has become "an authorising narrative which assisted in the denial of difference" (2001:98), a narrative that is reinforced in the language of an African identity. The emphasis on unity and a common African identity does serve as an antidote to colonial mentality, an overt textual approach that Makgoba and Seepe (2004) adopt. However, such an emphasis does, at the same time, hold the potential to preclude rigorous examination of the powerful intersections of race, class, gender, culture, language and sexual orientation, and how these factors influence access to power, privilege, status and resources (Gqola, 2001; Sewpaul, 2003a). Of all these socially defined criteria, race still remains the dominant factor in contemporary South Africa; it is still the majority of African black people in South Africa who are the poorest and it is still the African black woman who suffers the greatest onslaught of racism, sexism and poverty (Sewpaul, 2005).

It would seem that the reference to a unifying African identity hides the demoralising and devastating consequences of race differences and the institutionalised racism that remains pervasive in our society. In this respect Steyn (2001:xxxii) argues that "...the construction of race has been used to skew this society over centuries. If we prematurely banish it from our analytical framework, we serve the narrow interests of those previously advantaged, by concealing the enduring need for redress. To deal with the expressions of power, we have to call it by its name."

\section{EUROCENTRICISM VS AFROCENTRICISM AND THE AFRICAN IDEAL: THE DYNAMICS OF INCLUSION AND EXCLUSION}

Makgoba and Seepe (2004) seem to accord "an African identity" a mythologising (and almost magical) status. Thus "decolonising higher education" is seen to be synonymous with Africanising it; an "Africanisaton that will necessarily repudiate racism" (Makgoba \& Seepe, 2004:19, italics mine). It would appear to suggest a direct, linear link between Africanisation and a cure for the universal, complex problem of racism in all its manifestations. The African identity becomes inscribed with all that is "emancipatory and liberatory" as opposed to that which is "authoritarian, patriarchal and Eurocentric" (Makgoba \& Seepe, 2004:14), hence the call to replace the Eurocentric epistemology with an Afrocentric epistemology. This recreates, along modernist lines, a binary classification - a substitution of one hegemonic discourse with another hegemonic 
discourse, which together with essentialist notions of identity has the potential to lead to totalitarian discourses and practices. Foucault (1980) argued that one way to undermine a "truth" was not to counterpose it with another "truth", but to examine the discursive processes by which true and false statements become distinguished.

Lebakeng (2004:115), in a chapter in the text edited by Seepe (2004), argues that "The challenge lies in capacitating African academics in establishing an Afrocentric epistemological paradigm. Working against the realisation of this challenge is a growing uncritical, un-intellectual and antiintellectual phenomenon among South African universities" (emphasis mine). The sub-text that is striking here is that one has to make a choice between one or the other, and that one's academic and intellectual integrity is at stake if one does not choose the Afrocentric, which is inscribed with being critical and intellectual. Clearly such classification and underlying assumptions reinforce colonial patterns of "us" and "them", "we" and "they", and reproduces the project of "othering" that colonialism perfected. Fanon, a post-colonial theorist, in his analysis of violence and national consciousness in The Wretched of the Earth, makes us acutely aware of the need to move beyond simplistic binary conceptions in the struggle against colonialism.

Makgoba and Seepe (2004) provide overtly enunciated statements to support the claim that being African has nothing to do with colour or race, yet a reading of the more subtle aspects of the text reveals that the authors have difficulty in extricating themselves from the linking of African with race. This is not surprising, for African has taken on 'an illusion of ordinariness' in its equivalence to race as reflected in popular and official language, including census and policy documents in South Africa (Maré, 2001). For Maré, "the ideological continuities [of race thinking and race] and the manner of their reproduction" remain salient (2001:84). Makgoba and Seepe (2004) make explicit claims that Africanisation and the African identity is "not a matter of colour" (2004:42), that it "repudiates and transcends racism" and that the African identity is "inclusive and not exclusive" (2004:28). Yet, given the debates at hand in what would be a site of profound relevance, Makgoba (2004) uses the concept of "African" to reflect a population category. In his "University of KwaZulu-Natal: Hundred Days $1^{\text {st }}$ January to $9^{\text {th }}$ April 2004" report, he documents the following demographics among students: African 45\%, Indian 36\%, White $16 \%$ and Coloured $3 \%$. The same categories are used to reflect staff demographics. Also, UKZN student application and registration forms, to date, use "African" as a race category. The point that I emphasise here is the contradictory use of the category "African" - the intention is not to engage in debates around post-merger transformational agendas at the institution. It would seem that the ideological claim to unity and a non-racial identity is challenged by an instantiated competing ideology as reflected in daily social relations, texts and practical action. As Makgoba and Seepe are products of a society characterised by inherent tensions and contradictions around race, they are bound to reflect these contradictions. But, given their relative positions of power and status, the danger is that their views might actually be construed as "authorised truths" (Gqola, 2001:96), and the potential that such contradictory discourses hold for the dynamics of inclusion and inclusion must not be underestimated.

In an attempt to explore students' understanding of the concept, social work students, the majority of whom were Black African, in a classroom context ${ }^{1}$, were asked to write down some of their immediate thoughts on hearing the word "African". The majority of students (76 of the 108) who responded linked African to being black, and for the majority along with this some of its cultural

\footnotetext{
${ }^{1}$ This is by no means representative of the total population of students at UKZN. As the author is from the discipline of social work, she was interested in gaining some insight into social work students' interpretation of the concept "African”, given its central use in Seepe's and Makgoba's article.
} 
extensions. Twenty-four of the students located African within the context of geographic space, mainly South Africa, while four of these reflected a Pan-Africanist perspective, with some difficulty in de-linking it from racial ideologies. Eight of the students responded to the word "Africa" rather than "African", here too producing some surprising answers for an urban-based student population, e.g. with expressions such as: "wild fields of brown grasslands rolling on and on, a lion laying hidden"; "waterfalls, rivers, mountains", "hunting", "tribes" and "wild animals". Among those who linked African with being black, the majority used associated words like "longstanding struggles", "suffering", "resilience", "rural" "culture", "rituals", "tradition", "colourful", "curly hair", "power", "music", "drums", "heritage" and "beautiful". The overt negative associations included "diseases", "HIV/AIDS", "death", "violence" and "uncivilised". Despite the affirmation of Africanness and African identity in post-apartheid South Africa, it is disturbing to note some of the negative archetypal representations that students have inscribed in them. The following are a few examples:

"Black, unique, strong, survivor, not too much intelligent" (my emphasis. The statement perhaps reflects how the "other" is constructed in comparison to whites, who are intelligent, and to the debilitating and shameful effects of colonisation (Fanon, 1963; Cesaire, 1972) racism and race thinking.)

"Someone that is dangerous. Could harm me!" (Reflecting the kind of "negrophobia" of the kind that Fanon (1967) wrote about.)

The following could be a picture on a wall. For one student "African" conjured a stereotypical image of "Zulu huts with tribal people walking around holding shields and spears. Women doing African bead work and children playing in a nearby river."

The students' common sense assumptions of what African meant is a far cry from Makgoba's and Seepe's (2004) ideal. Africa, from the students' responses, emerges as two worlds juxtaposed one that they hold in their heads, an Africa with all its archetypal representations, and an Africa that they actually inhabit. Our students, who are of Africa live in a world of denim jeans, cellphones, TV, computers and concrete buildings, yet carry an Africa with wild flowers, mountains, tribes, rivers and wild animals. Not a single student produced any associative words in relation to the world that they actually live in. This, indeed, is interesting and an area that merits research in terms of its identity implications. On a universal level, the impact of oppression is such that oppressed people eventually turn societal and political oppression into self-oppression (Sewpaul, 2003b), and many of our students have been objects of oppression and exclusion.

Students need opportunities to engage in processes wherein identities and dominant social and political ideologies can be deconstructed. Of equal importance is the aim of providing students with a framework of options for the reconstruction of their identities by identifying external sources of exclusion and oppression (and of privilege), engaging in re-scripting or re-authoring of the self, and the building of action upon their strengthened identities. Action, reflection, deconstruction and reconstruction, which are central to emancipatory education (Sewpaul, 2003a), constitute the micro-foundation for development thinking and practice (Coetzee, 2001). The salient questions are who should work towards the kinds of emancipatory objectives that Makgoba and Seepe (2004) are talking about, and how is this to be done within the context of the university that is largely dominated by a technical logical-positivist, not an emancipatory, rationality? And how can the culture of teaching/learning and forms of assessment at institutions of higher learning be transformed to support emancipatory strategies? 
By Makgoba's use of the term (and as part of everyday discourse), 55\% of our student population at UKZN is excluded from being identified as African but as Indian, White and Coloured. Might they not then be or feel excluded from what is to be a university with "an African identity"? How might the experience of not belonging, among students designated by default as "non-African", impact on relationships in an "Africanised" university with "an African identity"?

Furthermore, African is linked with all that is emancipatory and liberatory (Makgoba \& Seepe, 2004:14), where the African identity is equated with "being in" and "belonging to" the world (2004:19). What then is the sub-text? Would those who are not designated African not be part of the emancipatory ideals of our society, and can they not be construed as being in and of the world of the university? Such interrogation is vital, for "race is not something that language simply describes, it is something that is created though language and institutional practices" (Maré, 2001:81, citing Noble). Given the contradictions and different meanings attached to a concept that is so central to Makgoba's and Seepe's arguments, their call for a universal acceptance of "an African identity" for institutions of higher learning might be predicated on false assumptions and a false ideology.

\section{AGAINST AN ESSENTIALIST EPISTEMOLOGY: MULTIPLE AND SHIFTING IDENTITIES}

Makgoba and Seepe (2004) make over 20 references to "an African identity". In addition there are references to "the African condition", "the African identity" (2004:19), "the African experience" (2004:31) and "the African world-view" (2004:41) (emphases mine). The language certainly reflects an essentialist position, with the presumption that there is a common African identity, a common African experience and a common African condition. There are common experiences in response to the impact of colonialism and racism, the struggles against oppression and white domination, and the struggle against the imperial gaze of shame induced by the coloniser (Fanon, 1970; Fanon, 1967). However, common experiences and struggles do not translate into a black essence and a single African identity (Hooks, 1990; Appiah, 2001). Kwame Appiah (2001:223), writing about African identities, cites Chinua Achebe acknowledging that "there isn't a final identity that is African." Appiah further notes: "Like all identities, institutionalised before anyone has permanently fixed a single meaning on them (...) being African, is for its bearers, one among other salient models of being, all of which have to be constantly fought for and refought" (2001:226). He adds to his notion of African identities "...the constantly shifting redefinition of 'tribal' identities to meet the economic and political exigencies of the modern world" (2001:226).

Identities exist in different historical and geographical spaces and at different societal levels, made more or less dominant, as one is subject to varied life experiences and as one traverses national boundaries. Within the South African context I occupy a "South African-Indian" hyphenated status, where there is an accentuated and generally accepted emphasis on being "Indian". Yet, on travelling internationally and on being labelled "Indian", my immediate reaction is "No, I am not Indian, I am South African." As a product of Black Consciousness, from the time of having developed a personal-political identity consciousness (Sewpaul, 2003a), I regarded myself as black, where blackness was seen as a site of resistance and transformation (Sewpaul, 2003a; Bohler-Muller, 2004). But this is not an identity that would now be ascribed to me by the majority of people. Ironically, even though I am of Africa, if I had to leave Africa I would not be seen to be part of the "African Diaspora", no matter how African my orientation and my world-view might be. By virtue of my physical characteristics and distant ancestral lineage, I would automatically be part of the "Asian Diaspora". This reflects both the absurdity and the power of the ordinariness of race as part of our lived experience. Posel, on providing a detailed account of racial classification 
under apartheid, claimed that the "habit of reading the symptoms of race [became] naturalised widely, even if not monolithically across the gamut of everyday life" (2001:51). Several students supported the notion of "African" being a "native of the land", meaning specifically black people. One student in providing her immediate reactions to the word "African" observed: "African means anyone who has their origins in Africa. For example, Indians have their origins in India. Whites have their origins in Europe."

Concluding his thesis on African identities - applicable to all identities - Appiah (2001:227-228) asserts:

"Identities are complex and multiple and grow out of a history of changing responses to economic, political and cultural forces, almost always in opposition to other identities ... $[\mathrm{T}]$ hey flourish ... despite ... their roots in myths and lies. And ... there is ... no large place for reason in the construction - as opposed to the study and the management - of identities. One temptation, then, for those who see the centrality of these fictions in our lives is to leave reason behind: to celebrate and endorse those identities that seem at the moment to offer the best hope of advancing our other goals."

Space and time mediate identities in profound ways. Bhabha (1994:1) contended that “...space and time come to produce complex figures of difference and identity, past and present, inside and outside, inclusion and exclusion." I have elsewhere (Sewpaul, 2003a) documented the experiences of African-American students who have been to UNZN on international placements. AfricanAmerican students arrive in South Africa with romanticised notions of returning to the motherland to find their roots, often characterised by a euphoric: "I got up this morning and I still can't believe that I am in Africa", or "It's hard to believe I am home". However, this sense of elation is often accompanied by intense mixed emotions, including sadness and anger linked to the African Diaspora and South Africa's recent apartheid past. Almost immediately students are confronted with the reality that they are more American than African, reflecting that the dialectics of culture, historical and self-identities, and national identities are indeed complicated. When confronted with the realities, it would appear that national identities gain primacy, despite the assertion by some that "All nations are imagined communities" (Muchie, 2003:370).

Fanon (1970) imparted a paradoxical insight, arguing that national consciousness (which is not nationalism) was the only thing to provide us with an international dimension. There is certainly a need for a common conception of collective action in relation to an integrated and structural transformation of Africa, and a united approach to dealing with systems and processes that have been massively unfair and unjust to Africa. This does call for a radical re-thinking and re-ordering of various sectors, including higher education, to counter the brutalising effects of colonialism and racism and the forces of neoliberal capitalist expansion. It is the common struggles, the exclusion and oppression of African peoples, slavery and the Trans-Atlantic slave trade that formed the basis of Pan-African ideology. At this level a Pan-Africanism that is "released from bondage to racial ideologies" (Appiah, 2001:229) can be a powerful, progressive force - where a common African identification can be "a constructive, unifying and enabling force", in the words of Makgoba and Seepe (2004:24). However, the impact of context on identities cannot be denied. Stuart Hall aptly sums up the notion of multiple and shifting identities in the following way:

"Identity is not only a story, a narrative which we tell ourselves about ourselves; it is stories which change with historical circumstances. And identity shifts with the way in which we think and hear them and experience them. Far from only coming from the still small point of truth inside us, identities actually come from outside, they are the way in which we are 
recognized and then come to step into the place of the recognitions which others give us. Without others there is no self, there is no self-recognition" (2001:285-286).

\section{CONCLUSION}

Adopting postmodernist emphases on plurality, diversity, multiple realities, different ways of knowing, language, power, deconstruction, the relational and contextual, and the politics of difference, I argue against the essentialist positions reflected by Makgoba and Seepe (2004) in their call for Afrocentricism and an African identity for institutions of higher learning in South Africa. There is no single world-view, identity, experience or condition that characterises Africa or being African. The historical and contemporary presence of the West in Africa, the "epistemicide (a destruction of African knowledge systems)" (Lebakeng, 2004:109) by the West and its damaging effects on the psyches of black people, means that it is imperative that we develop critical, emancipatory, anti-oppressive scholarship and pedagogical practice. That such a scholarship and practice must be rooted in our local context and be responsive to local realities is self-evident.

Emancipatory education raises important issues regarding how we construct our identities within particular historical, cultural and social relations, with the intention of contributing to a more democratic life, and it is consistent with the post-modern emphases identified above. In what he called an insurgent multiculturalism, Giroux (1994, 1997) called for discourses on multiculturalism which have been used to victimise minority groups, with an emphasis on their deficits and one which presents them as the "other", to be combined with discourses on power, racialised identities and class. In doing so, we need to move away from using white, which is a mark of racial privilege, as a point of departure in identifying difference. We need to develop a pedagogy in South Africa that seriously begins to engage with such issues, and one that works towards the deconstruction and reconstruction of identities, and towards transformation of higher education. If we accept that an emancipatory pedagogy is necessary for institutions of higher learning, we must then ask: "Why is it not really being sought?" Is it possible that there is a larger political project in that the class and wealth gap cannot be bridged (or that those in power do not wish to bridge) within the current socio-political and economic structures that we shift the discourse to that of identity, and that institutions of higher learning are being recruited into this project?

Since presenting this paper at the launch in August 2004, there have been some disturbing discourses in the media from Professor Makgoba (currently Vice-Chancellor of University of KwaZulu-Natal). In the Mail and Guardian (March 24-31, 2005) in a contribution entitled: "Wrath of dethroned white males", Makgoba likens the white male to the baboon and asserts the following:

The message should be loud and clear just as the writing is on the wall for all to whom South Africa belongs. All modern democratic societies celebrate diversity around a common vision, in our case an African vision. It should therefore become common sense that the white male soon learns to speak, write and spell in an African language; that he, like Johnny Clegg, learns to dance and sing like Ladysmith Black Mambazo. He should learn kwaito, dance like Lebo, dress like Madiba, enjoy eating "smiley and walkies"" and attend "lekgotla"3 and socialize at our taverns. He must soon accept, value and imitate the things that matter dearly to Africans.

\footnotetext{
${ }^{2}$ Meaning chicken heads and feet.

${ }^{3}$ Meaning tribal meeting.
} 
There is also a sinister warning that failure to transform according to the defined African ideal means that people will be "fingered, caught, and revealed" (Makgoba cited in Mail and Guardian March 24-31, 2005:23). While he was writing in relation to the white male, the message is clearly applicable to all South Africans who do not fit Makgoba's definition of being African. We must remember that human atrocities and genocides such as those committed by Hitler and in Darfur, Rwanda, the Congo and the former Yugoslavia, and the over fifty million refugees and displaced people across the world all did not happen in a day! Human atrocities and genocides are preceded by discourses such as Makgoba's, which promote the societal process of othering, paving the way for ethnocentricism, racial division, hate and violence. These discourses are certainly inconsistent with the kinds of emancipatory pedagogy and objectives that aught to be inscribed in institutions of higher learning.

Giroux (1983:2) contended that the spirit of radical or emancipatory pedagogy is "rooted in aversion to all forms of domination, and its challenge centres around the need to develop modes of critique fashioned in a theoretical discourse that mediates the possibility for social action and emancipatory transformation," a view that is of critical import to social work educators. Radical theorists believe in the dialectic of agency and structure, and developed theoretical perspectives that support the notion that history can be changed and provide potential for radical transformation. Such a scholarship and radical pedagogy are actually antithetical to any fossilised, essentialist notion of identity. The success and the making of universities in Africa are not dependent on an African identity, an African world-view, an African experience and on the African condition - in short on an Afrocentric epistemology - but on the emancipatory kinds of pedagogy and scholarship that we embrace. As social work practitioners and social work educators we must resist all forms of domination, variously and innumerably manifest within the broad categories of Afrocentricism or Eurocentricism.

\section{REFERENCES}

ALCOFF, L.M. 2002. Philosophy and racial identity. In: OSBORNE, P. \& SANFORD, S. (eds) Philosophies of race and ethnicity. London: Continuum.

APPIAH, K.A. 2001. African identities. In: CASTLE, G. (ed) Postcolonial discourses: An anthology. Oxford: Blackwell Publishers Ltd.

BALLARD, R. 2002. Desegregating minds: White identities and urban change in the New South Africa. Department of Geography, University of Wales: Swansea. (PhD Thesis)

BHABHA, H. 1994. The location of culture. New York and London: Routledge.

BOHLER-MULLER, N. 2004. Fluid identities and the possibilities inherent in transformative thought. In: SEEPE, S. (ed) Towards an African identity in higher education. Pretoria: Vista University and Scottaville Media.

CASTLE, G. (ed) 2001. Postcolonial discourses: An anthology. Oxford: Blackwell Publishers Ltd.

CESAIRE, A. 1972. Discourse on colonialism, New York: Monthly Review Press.

COETZEE, J.K. 2001. A micro foundation for development thinking. In: COETZEE, J.K.; GRAAFF, J., HENDRICKS, F. \& WOODS, G. (eds) Development: Theory, policy and practice. Cape Town: Oxford University Press. 
FANON, F. 1970. The wretched of the earth. Harmondsworth: Penguin Books.

FANON, F. 1967. Black skin white masks. New York: Grove Press.

FAIRCLOUGH, N. 1989. Language and power. Edinbourgh Gate, Harlow and Essex: Longman.

FOUCAULT, M. 1980. Power/Knowledge: Selected interviews and other writings 1972-1977. (trans by C. Gordon Hemel Hempstead). Harvester: Wheatsheaf.

FREIRE, P. 1970. The pedagogy of the oppressed. Harmondsworth: Penguin Books.

FREIRE, P. 1973. Education for critical consciousness. New York: The Seabury Press.

GIROUX, H.A. 1983. Theory and resistance in education: A pedagogy for the opposition. London: Heinemann Educational Books.

GIROUX, H. 1992. Border crossing: Cultural workers and the politics of education. New York: Routledge.

GIROUX, H.A. 1994. Living dangerously: Identity politics and the new cultural racism In: GIROUX, H.A. \& McLAREN, P. (eds) Between borders: Pedagogy and the politics of cultural studies. New York: Routledge.

GIROUX, H.A. 1997. Pedagogy and the politics of hope: Theory, culture and schooling. Colorado: Westview Press.

GQOLA, P. 2001. Defining people: Analysing power, language and representation in metaphors of the new South Africa. Transformation, 47:94-106.

GRAMSCI, A. 1971. Selections from the prison notebooks (ed and transl by Hoare, A. \& Smith, G.N.). London: Lawrence \& Wishart.

HABERMAS, J. 1996. Between facts and norms: Contributions to a discourse theory of law and democracy. Massachusetts: The MIT Press.

HALL, S. 2001. Negotiating Caribbean identities. In: CASTLE. G. (ed) Postcolonial discourses: An anthology. Oxford: Blackwell Publishers Ltd.

HOOKS, B. 1990. Talking back. Boston: South End.

LACLAU, E. 1995. Subject of politics, politics of the subject. Differences, 7(1):145-164.

LANSINK, A. 2004. The African University: Contestations in the production of knowledge and identity. In: SEEPE, S. (ed) Towards an African identity in higher education. Pretoria: Vista University and Scottaville Media.

LEBAKENG, T.J. 2004. Towards a relevant higher education epistemology. In: SEEPE, S. (ed) Towards and African identity in higher education. Pretoria: Vista University and Scottaville Media.

LEONARD, P. 1999. Postmodern welfare. Restructuring an emancipatory project. London, Thousand Oaks. 
LYOTARD, J.F. 2003. From the postmodern condition: A report on knowledge. In: CAHOONE, L. (ed) From modernism to postmodernism: An anthology. Oxford: Blackwell Publishing Ltd.

MAKGOBA, M. \& SEEPE, S. 2004. Knowledge and identity: An African vision of higher education transformation. In: SEEPE, S. (ed) Towards an African identity in higher education. Pretoria: Vista University and Scottaville Media.

MARÉ, G. 2001. Race counts in contemporary South Africa: "An illusion of ordinariness". Transformation, 47:75-93.

MARÉ, G. 2002. Thinking about race and race thinking. Inaugural address. Durban: University of Natal.

MIDGLEY, J. 2000. Globalization, capitalism and social welfare: A social development perspective. In: ROWE, B. (ed) Social work and globalization. Ottawa: Canadian Association of Social Workers.

MUCHIE, M. 2003. NEPAD: Can it succeed without reforming the global economic system. In: MUCHIE. M. (ed) The making of the Africa-Nation: Pan Africanism and the African Renaissance London: Adonis \& Abbey Publishers Ltd.

POSEL, D. 2001. What's in a name: Racial categorisations under apartheid and their afterlife. Transformation, 47:50-74.

SEEPE, S. 2004. Towards an African identity in higher education. Pretoria: Vista University and Scottaville Media.

SEWPAUL, V. 2003a. Reframing epistemologies and practice through international exchanges: Global and local discourses in the development of critical consciousness. In: DOMINELLI, L.D. \& BERNARD, W.T. (eds) Broadening horizons: International exchanges in social work. Aldershot: Ashgate.

SEWPAUL, V. 2003b. The Caribbean - South African Diaspora: Towards locally specific social work education and practice. Caribbean Journal of Social Work, 2:23-142.

SEWPAUL, V. \& HOLSCHER, D. 2004. Social work in times of Neoliberalism: A postmodern discourse. Pretoria: Van Schaik Publishers.

SEWPAUL, V. 2005. Feminism and globalization: The promise of Beijing and neoliberal capitalism in Africa. Agenda, 64:104-113.

STEYN, M.E. 2001. Whiteness just isn't what it used to be: White identity in a changing South Africa. Albany: State of New York Press.

TERRE BLANCHE, M. \& DURRHEIM, K. 1999. Social constructionist methods. In: TERRE BLANCHE, M. \& DURRHEIM, K. (eds) Research in practice. Applied methods for the social sciences. Cape Town: University of Cape Town Press.

TOMLINSON, J. 1991. Cultural imperialism: A critical introduction. Baltimore: The Johns Hopkins University Press. 
WETHERELL, M. \& POTTER, J. 1992. Mapping the language of racism: Discourse and the legitimation of exploitation. New York: Harvester Wheatsheaf.

WILLIAMS, L.O. \& SEWPAUL, V. 2004. Modernism, postmodernism and global standards setting. Journal of Social Work Education, 23(5):555-565.

Prof Vishanthie Sewpaul, Postgraduate Programme Director, Centre for Social Work, University of KwaZulu-Natal, Howard College Campus, Durban, South Africa. 